EDITORIAL

\title{
Consequences of COVID-19 for markets and productive systems
}

\author{
Syed Abdul Rehman Khan ${ }^{1,2}$ \\ Managing Editor of the Special Issue \\ ${ }^{1}$ School of Management and Engineering, Xuzhou University of Technology, Xuzhou, China. \\ ${ }^{2}$ Beijing Key Laboratory of Urban Spatial Information Engineering, Beijing, China.
}

How to cite: Khan, S.A.R. (2021), "Consequences of COVID-19 for markets and productive systems", Brazilian Journal of Operations \& Production Management, Vol. 18, No. 2, e20211261.

https://doi.org/10.14488/BJOPM.2021.041

\begin{abstract}
In December 2019, the first case of COVID-19 was diagnosed in Wuhan city of China. The virus spread in several countries quickly and created pressure on the global supply chain and production systems. Undeniably, due to COVID-19, the world economy has been badly disrupted, which required a couple of years to restore. This special issue mainly uncovers the difficulties and challenges faced by firms during the COVID-19 outbreak. Also, the special issue covered the innovative approaches and applications of digital technologies to control the spread of COVID-19 and mitigating the harmful effects on economic activities through promoting teleworking and virtual business activities.
\end{abstract}

Keywords: Global supply chain; COVID-19; Innovative approaches; Digital capabilities.

\section{INTRODUCTION}

COVID-19 outbreak in Wuhan city of China. In a few couples of weeks, the virus converted the world into a dangerous situation (Janjua et al. 2021). There is no doubt that COVID-19 is not only damaged to society but also slowdown to the economic activities (Yu and Khan, 2021). Due to panic and lockdown policies, people started buying groceries in bulk, which started pressure on different echelons, including retailers, manufacturers, and producers (Nikolopoulos et al. 2020). Disturbances in both supply and demand were created, deepening, even more, the bullwhip effect and generating shortages in supply, workers, and ancillary, in addition to price fluctuations (Jesus and Nascimento, 2021; Yu and Khan 2021).

In this context, serious concerns are raised about the markets and production system to face this chaotic disruption and find innovative approaches to reduce the harmful effects of COVID-19 on markets and productive systems (lqbal et al. 2021). To deal with this pandemic, firms need to increase their resiliency (Cordeiro et al. 2021; Belhadi et al. 2021). The definition of resilience is 'the ability of a system to return to its original state after being disturbed' (Pettit et al. 2019; Min 2019, pp. 6-8).

Researchers noted that this pandemic is difficult to handle with traditional approaches, but digital technologies can play a vital role in effective and smart lockdown (Dolgui et al. 2020; Golpîra et al. 2021), timely delivery of products, teleworking and virtual activities to avoid physical contacts, etc.

Financial support: This research is supported by the Beijing Key Laboratory of Urban Spatial Information Engineering (NO. 20210218) and National Natural Science Foundation of China (No. 202202457).

Conflict of interest: The authors have no conflict of interest to declare.

Corresponding author: sarehman_cscp@yahoo.com

Received: 9 June 2021.

Approved: 9 June 2021.

Editor: Julio Vieira Neto. 
This Special Issue (SI) aims to compile technological approaches and novel research modeling, which will build a new body of knowledge to assist practitioners and policymakers in increasing the resilience of markets and production systems to combat the COVID-19 pandemic.

\section{THE SPECIAL ISSUE}

This SI collected the articles from different researchers involved in supply chain operations, industrial management, economics and technology. The criteria of article selection were based on the novelty and originality of the article. In the initial stage, the Editor checks the article's suitability if the article meets the journal's standard. In the second stage, the article assigns to the reviewers for blind peer-review.

\section{CONCLUSION}

Since December 2019, the spread of the COVID-19 virus has created challenges and difficulties for the economy and society. The SI objective was to highlights the consequences of COVID-19 and explored the innovative and technological approaches, which can mild the intensity and increase the firm's resiliency. This SI collected high-quality papers supported by both qualitative and quantitative approaches. This SI provided insightful knowledge that benefits from the global experience on COVID-19 and contributes to increasing resiliency of markets and production systems through innovative approaches and digital capabilities.

\section{REFERENCES}

Belhadi, A., Kamble, S., Jabbour, C.J.C. et al. (2021), "Manufacturing and service supply chain resilience to the COVID-19 outbreak: lessons learned from the automobile and airline industries", Technological Forecasting and Social Change. http://dx.doi.org/10.1016/j.techfore.2020.120447.

Cordeiro, M., Santos, L. and Marujo, L.G. (2021), "COVID-19 and the fragility of Brazilian small farming resilience", Brazilian Journal of Operations \& Production Management, Vol. 18, No. 2, pp. 1-14. https://doi.org/https://doi.org/10.14488/BJOPM.2021.027.

Dolgui, A., Ivanov, D., Potryasaev, S. et al. (2020), "Blockchain-oriented dynamic modelling of smart contract design and execution in the supply chain", International Journal of Production Research, Vol. 58, No. 7, pp. 2184-99.

Golpîra, H., Khan, S.A.R. and Safaeipour, S. (2021), "A review of logistics internet-of-things: current trends and scope for future research", Journal of Industrial Information Integration, Vol. 100194. http://dx.doi.org/10.1016/j.jii.2020.100194.

Iqbal, M., Ahmad, N., Waqas, M. et al. (2021), "COVID-19 pandemic and construction industry: Impacts, emerging construction safety practices, and proposed crisis management", Brazilian Journal of Operations \& Production Management, Vol. 18, No. 2, pp. 1-17. https://doi.org/https://doi.org/10.14488/BJOPM.2021.034.

Janjua, L.R., Muhammad, F., Sukjai, P. et al. (2021), "Impact of COVID-19 pandemic on thailand economy and tourist industry: an empirical forecasting using ARIMA", Brazilian Journal of Operations \& Production Management, Vol. 18, No. 2, pp. $1-13$. https://doi.org/https://doi.org/10.14488/BJOPM.2021.001.

Jesus, I.R.D. and Nascimento, P.P. (2021), "ESG strategies to deal with COVID-19 in a Brazilian public research company", Brazilian Journal of Operations \& Production Management, Vol. 18, No. 2, pp. e20211153. http://dx.doi.org/10.14488/BJOPM.2021.028.

Min, H. (2019), "Blockchain technology for enhancing supply chain resilience", Business Horizons, Vol. 62, No. 1, pp. 35-45.

Nikolopoulos, K., Punia, S., Schäfers, A. et al. (2020), "Forecasting and planning during a pandemic: COVID19 growth rates, supply chain disruptions, and governmental decisions", European Journal of Operational Research, Vol. 290, No. 1, pp. 99-115. http://dx.doi.org/10.1016/j.ejor.2020.08.001. 
Pettit, T.J., Keely L.C. and Joseph, F. (2019), "The evolution of resilience in supply chain management: a retrospective on ensuring supply chain resilience", Journal of Business Logistics, Vol. 40, No. 1, pp. 56-65.

Yu, Z. and Khan, S.A.R. (2021), "Evolutionary game analysis of green agricultural product supply chain financing system: COVID-19 pandemic", International Journal of Logistics Research and Applications, https://doi.org/10.1080/13675567.2021.1879752. 